\title{
Testing the Quality of Biofertilizer Illetrisoy
}

\author{
Tutik Prihast ${ }^{*}$ \\ Indonesian Legume and Tuber Crops Research Institute, Malang, East Java, Indonesia \\ *Corresponding author: tutikprihastutik@yahoo.com
}

Received November 01, 2013; Revised January 29, 2014; Accepted March 20, 2014

\begin{abstract}
This is a descriptive analytical study, aims to assess the quality of bio-fertilizers Illetrisoy up to viability resilience bacterial during the storage. Illetrisoy A and B are the two types of biological fertilizers that contains of beneficial bacterial to improving growth and productivity of soybean. The research conducted covers the identification of the microbial are contained in the biological fertilizer Illetrisoy, the characterization of carrier matter and the viability of bacteria on the carrier matter during storage in different of packaging (plastic bag, allumunium foil, and plastic bottle) and storage temperature (refrigerator, room temperature, and incubator $40^{\circ} \mathrm{C}$ ). The research shows that Illetrisoy A and Illetrisoy B contain 4 species of bacteria from the genus Phaenibacillus and Bacillus. The carrier of Illetrisoy is a mixture of RawaPening peat soil and charcoal powders provides a good quality in Illetrisoy A ( $\mathrm{pH}$ 6.75, C $22.13 \mathrm{~g} \mathrm{~kg}^{-1}, \mathrm{~N} 1.32 \mathrm{~g} \mathrm{~kg}^{-1}, \mathrm{P}_{2} \mathrm{O}_{5} 389 \mathrm{mg} \mathrm{kg}^{-1}, \mathrm{~K} 2.68 \mathrm{cmol} \mathrm{kg}^{-1}$ and microbial population $36.5 \times 10^{8} \mathrm{cfu} \mathrm{g}{ }^{-1}$ of matter) and Illetrisoy B (pH 6.92, C $21.74 \mathrm{~g} \mathrm{~kg}^{-1}, \mathrm{~N} 1.25 \mathrm{~g} \mathrm{~kg}^{-1}, \mathrm{P}_{2} \mathrm{O}_{5} 412 \mathrm{mg} \mathrm{kg}^{-1}, \mathrm{~K}^{-1.47} \mathrm{cmol}$ $\mathrm{kg}^{-1}$ and microbial population $34.9 \times 10^{8} \mathrm{cfug}^{-1}$ of matter). The product of biological fertilizer Illetrisoywith water content $50-60 \%$ could be stored in the plastic packaging bags and be placed in refrigerator temperature $4^{\circ} \mathrm{C}$. On the conditions of storage, the product of biological fertilizers Illetrisoy can be survived for 3 months, with the viability of bacteria preserved on the total population of $10^{8} \mathrm{cfug}^{-1}$ of matter.
\end{abstract}

Keywords: Illetrisoy, quality, bio-fertilizer

Cite This Article: Tutik Prihast, "Testing the Quality of Biofertilizer Illetrisoy." American Journal of Microbiological Research, vol. 2, no. 2 (2014): 63-67. doi: 10.12691/ajmr-2-2-4.

\section{Introduction}

Illetrisoy is a biological fertilizer that contains beneficial microbes for growth and production of soybean [1]. Illetrisoy has been widely applied to soybean crops in marginal lands such as acid and non-acid dry land. Now, this product is ready to be marketed, so this quality should be maintained in order to avoid a decline in confidence of farmers on the benefits of bio fertilizer [2]. Various studies indicate that the application of bio-fertilizers in accordance with the functional character of inoculant proven to reduce the use of single fertilizer NPK [3]. But of course, the effectiveness of the microbes contained in the biological fertilizer products in the supply of nutrients is highly dependent on the power of life and its development in the rhizosphere [4].

In an effort to make improvements of Illetrisoy products, it is necessary to study the quality of this product. The study was conducted at the laboratory scale, start from to maintenance and characterized of species bacterial, to develop of cell bacterial multiply and product formulation, and to maintenance the viability of bacteria on storage, with the expected results can give an idea of success to be produced at the plant scale and can be applied at the field scale.

The success of this study will be provides essential information to the character of the microbial bio-fertilizers constituent, the properties of the carrier matter and the microbial viability during storage. Accordingly the handling of biological fertilizers start from the production process until to the period of storage can be well controlled, to maintain the quality of the biological fertilizer Illetrisoy.

\section{Materials and Methods}

The study was conducted at the Indonesian Legumes and Tubers Crop Research Institute (ILETRI), Malang and Indonesian Institute of Sciences, Cibinong in year2012.The microbial source is the bacterial collection of ILETRI (KDL-92, KDL-182, KDL-176andKDL-196). Characterization of bacterial in Illetrisoy product is performed by PCR analysis in the Department of Microbiology, Indonesian Institute of Sciences.

Carrier material used is a mixture of Rawa Pening peat soil and charcoal powder with a ratio of $3: 1$. The characterization of carrier material is described by analyzing the nutrient content of the material (include of $\mathrm{C}$, $\mathrm{N}, \mathrm{P}$, and $\mathrm{K}$ ) and the amount of microbial populations by pour plate method.

Illetrisoy product is packaged in 3 different shapes, in the plastic bag, allumunium foil and plastic bottles. Once every 10 days, the total population of microbes was observed with pour plate method to identify their viability.

\section{Results and Discussion}


The results of DNA sequencing for 4 (four) isolates bacterial of Iletrisoy constituent, can be determined the general properties of bacterial (Table 1.). This analysis shows there are 3 (three) isolates which was derived from the same genus Paenibacillus. The advantages of this genus is the ability to form spores, thus survival can be maintained better and can last longer in storage, caused by the spore as a form of survival under unfavorable environmental conditions and will develop into microbial cells under conditions that are suitable for life again [5]. Paenibacillus is also able to nitrogen fixing and produce of growth plant subtance, so it can be used as bio fertilizer [6]. There are several types of bacteria that can produce anti-microbial substances, so it can be used as biopesticide agents $[7,8]$. One type of Illetrisoy constituent is Bacillus pumillus, which have the property can nitrogen fixing and produce anti-bacterial and anti-fungal substances that can be used as a biological control agent $[9,10,11,12]$.

In reality, a single of microbes may has the ability function more than of the categories, so that may its functions as a growth promoting, nutrient supply (direct functions) and is also at the same time controlling of pathogens (indirect functions) whenever one to another that can't be separated $[13,14]$. Plants that the developing and growing roots system properly, not susceptible to pathogens (disease), and otherwise that pathogens plant affected will not growing well even though sufficient nutrients [15]. By knowing of Illetrisoy bacterial characteristics, it can be determined a further step in the determination of the portion of each isolate was in the biological fertilizer formulation, based on their activities that have been measurable.

Table 1. Result ofDNA sequencing analysis of Illetrisoy bacterial and its generalcharacteristic

\begin{tabular}{|c|c|}
\hline Code of isolat & DNA sequencing \\
\hline KDL-92 & $\begin{array}{l}\text { JF701948|JF701948.1 Paenibacillus } \text { sp. YXA3-5 16S } \\
\text { ribosomal RNA g.. } \\
\text { Identities }=1127 / 1138 \text { (99\%), Gaps }=8 / 1138(0 \%)\end{array}$ \\
\hline KDL-196 & $\begin{array}{l}\text { JQ735955|JQ735955.1 Paenibacillus ourofinensis } \\
\text { strain TS44 16S r... } 1437 \quad 0.0 \text { Identities }=780 / 789 \\
(98 \%) \text {, Gaps }=7 / 789(0 \%)\end{array}$ \\
\hline KDL-182 & $\begin{array}{l}\text { AB366300|AB366300.1 Paenibacillus sp. SBI-16 gene } \\
\text { for } 16 \text { S riboso... } 244 \text { 193/207 (93\%), Gaps = 7/207 } \\
(3 \%)\end{array}$ \\
\hline KDL-176 & $\begin{array}{l}\text { >1024589_M145_520_F (Bacillus pumilus, } 1472 \text { bits, } \\
797 \text { bp, 100\%, 0.0, acc. no: HF536558.1) }\end{array}$ \\
\hline
\end{tabular}

The specific growth rate $(\mu)$ of each Illetrisoy bacterialis also been determined(Table 2). It is known that there are two groups of bacteria, there are a medium growing bacterial(double time4-6hours) with a symbol $++($ KDL-92 andKDL-182) and a fast growing bacterial (double time2-4hours) with a symbol+++(KDL-196 andKDL-176). The big difference in the generation time of each bacteria lisolates indicates a difference in the capabilities isolates of to reproduce them self through the binary fission. Therefore, how much the number of cells that will be used in the formulation of biological fertilizers should be adjusted to the time of cell harvest of each isolate, so that composition of microbe cells in the biological fertilizer formulation may guaranteed to be active on the exponential phase.

Table 2. Result of measurement of the specific growth rate bacterial of Illetrisoy component

\begin{tabular}{ccccc}
\hline No. & Isolate code & $\boldsymbol{\mu}$ (/hour) & $\mathbf{g}$ (hour) & Growth categories \\
\hline 1. & KDL- 92 & 0.1327 & 5.22 & ++ \\
2. & KDL-196 & 0.2172 & 3.19 & +++ \\
3. & KDL-182 & 0.1224 & 5.66 & ++ \\
4. & KDL-176 & 0.1853 & 3.74 & +++ \\
\hline
\end{tabular}

Notes: ++ : mediumgrowing, +++ : fastgrowing

The study of the Rawa Pening peat soil characteristics shows that on the field condition have a pH value of 6.82 and a water content of $46.31 \%$. Total microbial population of the field condition is $11.4 \times 10^{5} \mathrm{cfug}^{-1}$ of soil. This matter is different from peat soil from other areas, which are usually acidic [16]. The Rawa Pening peat soil has Corganic content of $3.10 \mathrm{~g} \mathrm{~kg}^{-1}$ and an average $\mathrm{N}$ content is $0.27 \mathrm{~g} \mathrm{~kg}^{-1}$ which can be considered to have a medium value dignity [17]. Ratio $\mathrm{C} / \mathrm{N}$ showed that the capability
General characteristic

Genus are facultative anaerobic, capable of nitrogen fixing, produce an extracellular enzymes, anti-microbial and plant growth promoting substances, used to bio-fertilizer and bio-pesticides.

Gram-positive bacterial, fast growing, rod-shaped or chain of rods, motile, spore-forming, mesophilic, facultative anaerobic.

The genus are facultative anaerobic, capable of nitrogen fixing, produce an extracellular enzymes, anti-microbial and plant growth promoting substances, used to bio-fertilizer and bio-pesticides.

The spores-forming bacterial, rod-shaped cells, gram-positive, aerobic, capable of as an anti-bacterial and an anti-fungal, produces of protease enzymes, capable of nitrogen fixing from the air.

of RawaPening peat soil as a good organic source for plant growth (the average of ratio $\mathrm{C} / \mathrm{N}$ 11.48). Not surprisingly, at this point the RawaPening peat soil is marketed as compost, which is good to plant growth medium.

Table 3. Result of the RawaPening peat soil analysis after wind dried process

\begin{tabular}{cc}
\hline Parameter (unit) & Value \\
\hline $\mathrm{pH}$ & 7.00 \\
C-organic $\left(\mathrm{g} \mathrm{kg}^{-1}\right)$ & 3.10 \\
$\mathrm{~N}$-organic $\left(\mathrm{g} \mathrm{kg}^{-1}\right)$ & 0.27 \\
$\mathrm{P}_{2} \mathrm{O}_{5}\left(\mathrm{mg} \mathrm{kg}^{-1}\right)$ & 15.60 \\
$\mathrm{~K}\left(\mathrm{cmolkg}^{-1}\right)$ & 0.43 \\
$\mathrm{CEC}\left(\mathrm{cmolkg}^{-1}\right)$ & 62.90 \\
Total of microbe $\left(\mathrm{cfug}^{-1}\right.$ soil) & $13.7 .10^{4}$ \\
\hline
\end{tabular}

P levels of Rawa Pening peat soil categorized were low (5-7 $\mathrm{g} \mathrm{kg}^{-1}$ ), after conversion multiplied by $0.44[17]$. $\mathrm{K}$ levels categorized is also quite high, so whenever if the Rawa Pening peat soil is used as a growing medium, the plant responses to $\mathrm{K}$ fertilization is not so apparent, because the content of $\mathrm{K}$ soil $>0.4 \mathrm{cmol} \mathrm{kg}^{-1}[17]$. CEC value indicates capabilities the soil in the provide nutrients. CEC value of Rawa Pening peat soil is classified as very high (> $40 \mathrm{c} \mathrm{mol} \mathrm{kg}^{-1}$ ), as it contains organic matter that is high enough anyway.

The composition of carrier material is used the Rawa Pening peat soil after wind dried and powdered charcoal with a ratio of 3:1 and sterilized beforehand. Of the mixture have a $\mathrm{pH}$ value of 7.58 and an average water content of $4.80 \%$. After the sterilization process of material carrier is carried out to inject bacterial suspension with an end product of biofertilizer Illetrisoy listed in Table 4. 
Table 4. Quality of Illetrisoy A and Illetrisoy B

\begin{tabular}{cccc}
\hline \multirow{2}{*}{ Parameter } & \multirow{2}{*}{ Unit } & \multicolumn{2}{c}{ Result of analysis } \\
\cline { 3 - 4 } & & Illetrisoy $A$ & Illetrisoy B \\
\hline $\mathrm{pH} \mathrm{H} \mathrm{H}_{2} \mathrm{O}$ & - & 22.13 & 6.92 \\
$\mathrm{C}$-organic & $\mathrm{g} \mathrm{kg}^{-1}$ & 1.32 & 21.74 \\
$\mathrm{~N}$ & $\mathrm{~g} \mathrm{~kg}^{-1}$ & 16.77 & 1.25 \\
$\mathrm{C} / \mathrm{N}$ Ratio & - & 389 & 17.39 \\
$\mathrm{P}_{2} \mathrm{O}_{5}$ & $\mathrm{mg} \mathrm{kg}^{-1}$ & 2.68 & 412 \\
$\mathrm{~K}$ & $\mathrm{cmol} \mathrm{kg}^{-1}$ & $36.5 \times 10^{8}$ & $34.9 \times 10^{8}$
\end{tabular}

Total of microbe on the Rawa Pening peat soil is 11.4 $\mathrm{x} 10^{5} \mathrm{cfug}^{-1}$ of soil. Besides microbes are aerobic, the anaerobic microbe is also found. After experiencing of the wind dried process, the peat soil physical condition changed on the moisture content, with a change in $\mathrm{pH}$ toward neutral (Table 2). After the wind dried process, total microbe contained in Rawa Pening peat soil decreased to $13.7 \times 10^{4} \mathrm{cfug}^{-1}$ of soil. Total microbe population is categorized as moderate, considering the microbial content in the bio-fertilizers on average $10^{7}$ $10^{9} \mathrm{cfug}^{-1}$ of material. The microbial content needs to be disabled or turned off, so as not to affect the biological activity of microbe on constituent of biofertilizer.

The Rawa Pening peat soil is chosen, because it has a good moisture characteristics of indicated by the high water holding capacity as well as the greater loss of water required to change the potential [18]. The viability of bacteria on the peat soil carrier influenced by the organic matter in the form of insoluble particles such as carbohydrates, proteins, and organic acids contained in peat as a source of carbon and energy for microbe metabolic activity. The viability and stability of bacteria is also determined by capabilities peat to maintain water content, $\mathrm{pH}$ neutral peat and the ability the bacteria to utilize carbon sources and energy sources that exist on the peat and the survival strategies the bacteria by using mechanisms that are owned by the respective efficiency each type [19].

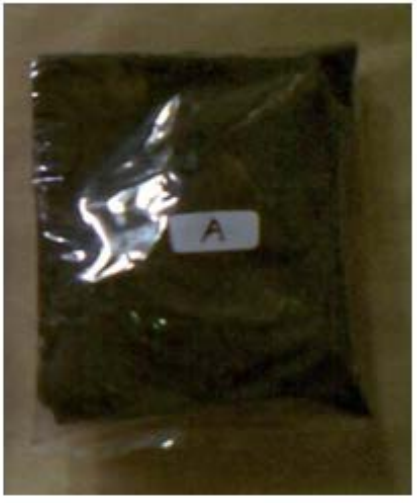

Illetrisoy in plastic bag packaging

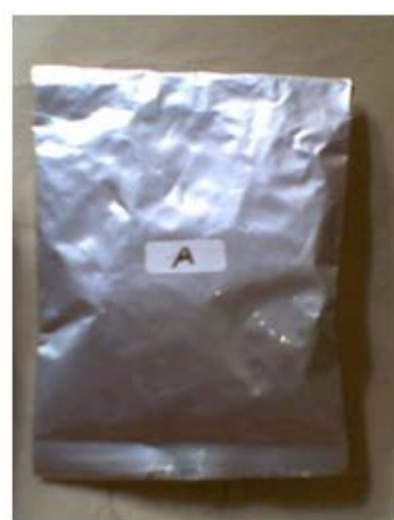

Illetrisoy in alumunium foil packaging

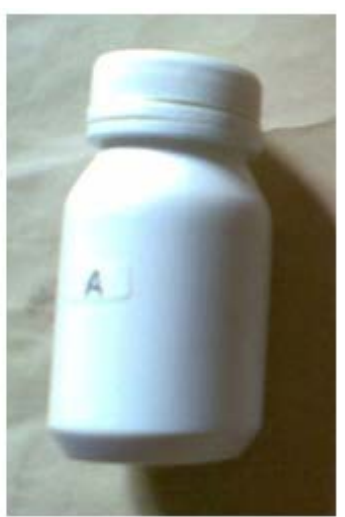

Illetrisoy in plastic bottle packaging

Figure 1. Biofertilizer of Illetrisoy on three packaging shapes

The composition of Illetrisoy biological fertilizer has a $\mathrm{pH}$ value and the amount of bacterial populations such as Table 6. From this starting composition will followed its development every 10 days of observation to a decline in the quality of bio fertilizers in the different storage conditions (temperature of $4^{\circ} \mathrm{C}$ in a refrigerator, room temperature at $27^{\circ} \mathrm{C}$, and in the incubator temperature $\left.40^{\circ} \mathrm{C}\right)$.

Table 6. pH value and total populations of bacteria at biofertilizer Illetrisoyin some packaging

\begin{tabular}{cccc}
\hline Illetrisoyin some packaging & & \\
\hline \multirow{2}{*}{ Packaging } & Water content (\%) & $\mathrm{pH}$ value & $\begin{array}{c}\text { Total of bacteria } \\
\text { (cfug } \text { of matter }^{-1}\end{array}$ \\
\hline 30 & 7.04 & $39.7 \times 10^{8}$ \\
Plastic bag & 40 & 7.00 & $36.9 \times 10^{8}$ \\
& 50 & 6.99 & $45.6 \times 10^{8}$ \\
Alluminium foil & 60 & 6.98 & $58.5 \times 10^{8}$ \\
\hline 30 & 7.00 & $39.2 \times 10^{8}$ \\
& 50 & 7.00 & $39.5 \times 10^{8}$ \\
Plastic bottle & 60 & 7.04 & $43.7 \times 10^{8}$ \\
& 30 & 6.99 & $49.3 \times 10^{8}$ \\
\hline
\end{tabular}

Figure 2 showed the number of bacterial populations on the Illetrisoy biological fertilizers during the storage, with a time of interval sampling 10 days. In fact there is the same trend in the decline in the number of bacteria cells during storage of on the variety of package (plastic bags, allum unium foil and plastic bottles), the average shows a decline starts on the sampling day 9-10 or 90-100 days of storage. Of the three conditions is shown that the storage on the refrigerator more resilient than those stored at room temperature and incubator. The condition of the refrigerator caused the bacteria cells will enter a period of dormancy better than on the other storage conditions. Differences in packaging not show significant a difference on the calculation of the amount of bacterial populations. Differences in packaging will affect the cost and the level of difficulty in the packaging process only.

The viability of bacteria is better to could maintain at water content material by 50-60 \%. It is advisable to could make biological fertilizers Illetrisoy on the water content 50-60 \%. From the observations on the bacteria population during storage of Illetrisoy bio fertilizer with different package, it can be suggested that the package with a plastic bags better to do because it is cheap, easily available and quite simple in handling and transportation. Storage period may performed on the refrigerator or a cool place (temperature $4^{\circ} \mathrm{C}$ ) not more for 3 months. 


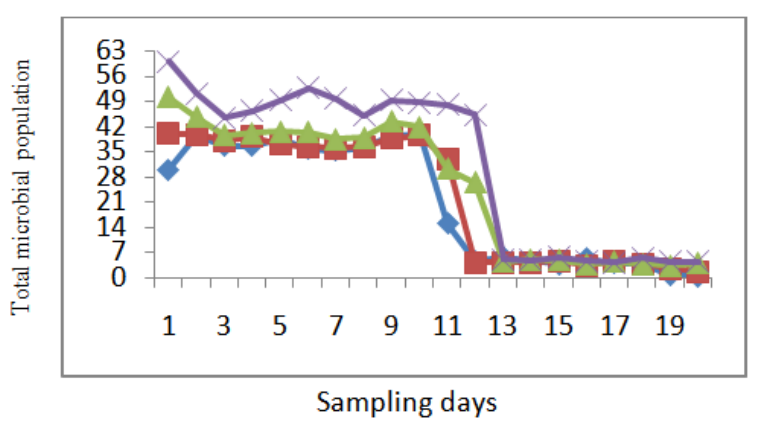

A. Illetrisoy in refrigerator storage

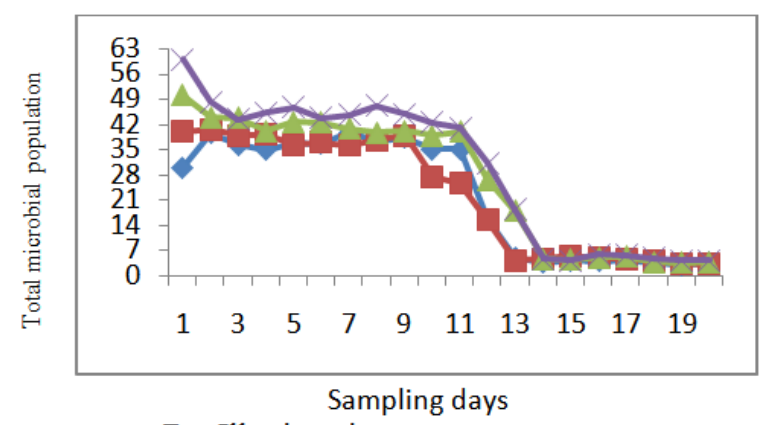

B. Illetrisoy in room temperature storage

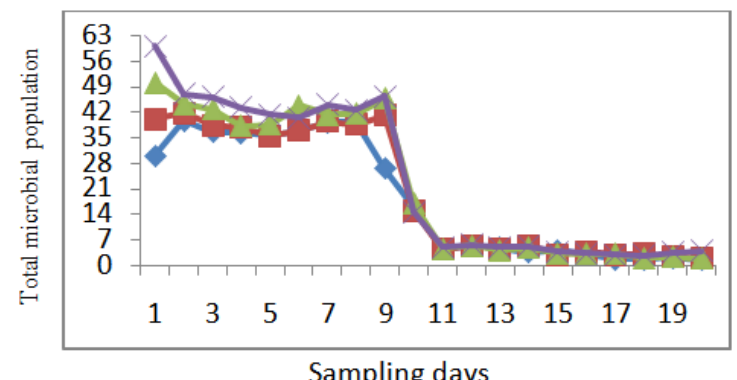

C. Illetrisoy in $40^{\circ} \mathrm{C}$ incubator storage

Figure 2. Total of bacteria population at bio-fertilizer Illetrisoy during storage, Notes: Water contentof matters: $\square=30 \%, \square=40 \%$, $\square=$ $50 \%$, $=60 \%$

\section{Conclusion}

1. There are two genera of bacteria that known by authors of Illetrisoy $\boldsymbol{A}$ and Illetrisoy $\boldsymbol{B}$ are Phaenibacilus and Bacillus. The PCR analysis of two species bacteria known to exist were identified as Bacillus pumilus and Paenibacillus ourofinensis.

2. Carrier material consisting of a mixture of Rawa Pening peat soil and charcoal powder with a ratio of 3:1 has meets criteria to produce bio fertilizer with a quality product: Illetrisoy A (pH 6.75, C $22.13 \mathrm{~g} \mathrm{~kg}^{-1}$, $\mathrm{N} 1.32 \mathrm{~g} \mathrm{~kg}^{-1}, \mathrm{P}_{2} \mathrm{O}_{5} 389 \mathrm{mg} \mathrm{kg}^{-1}, \mathrm{~K} 2.68 \mathrm{cmol} \mathrm{kg}^{-1}$ and a total population of $36.5 \times 10^{8} \mathrm{cfug}^{-1}$ of matter) and Illetrisoy $\boldsymbol{B}\left(\mathrm{pH}\right.$ 6.92, C $21.74 \mathrm{~g} \mathrm{~kg}^{-1}, \mathrm{~N} 1.25 \mathrm{~g}$ $\mathrm{kg}^{-1}, \mathrm{P}_{2} \mathrm{O}_{5} 412 \mathrm{mg} \mathrm{kg}^{-1}, \mathrm{~K} 2.47 \mathrm{cmol} \mathrm{kg}^{-1}$ and a total population of $34.9 \times 10^{8} \mathrm{cfug}^{-1}$ of matter).

3. The product of Illetrisoy with water content 50-60\% provides hope for is stored in simple packaging in plastic bags for 3 months of storage in a refrigerator temperature.

\section{Acknowledgments}

Author wishes to thank to Prof. Arif Harsono, Prof. Subandi and Prof. I Made Sudiana for their kind technical support in executing this research. This research was funded by the government from the fiscal year 2012 .

\section{References}

[1] Harsono, A., Subandi, dan Suryantini, 2010. Formulasi pupuk hayati dan organik untuk meningkatkan produktivitas aneka kacang 20\%, ubi $40 \%$ menghemat pupuk kimia 50\%. Laporan Penelitian 2010. Balitkabi.53 hal.
[2] Husen, E., R.D.M. Simanungkalit, and Irawan. 2007. Characterization and quality assessment of Indonesian commercial biofertilizers. Indonesian Journal of Agricultural Science 8:31-38.

[3] Makarim, K., F. Islam, M. A. Akkas Ali, F. Haque. 2001. Onfarmtrail with Rhizobium inoculants on lentil. Bangladesh J. Agric Res 26, 93-94.

[4] Husen, E. 2009. Telaah efektivita spupuk hayati komersial dalam meningkatkan pertumbuhan tanaman. Prosiding Seminar dan Lokakarya Nasional Inovasi Sumberdaya Lahan, Bogor 24-25 November 2009. Balai Besar Penelitian dan Pengembangan Sumberdaya Lahan Pertanian, Badan Penelitian dan Pengembangan Pertanian. Pp. 418-423.

[5] Anas, I., D. A. Santoso dan Y. Fakuara. 1992. Bioteknologi Pertanian 2. Pusat Antar Universitas Bioteknologi, Institut Pertanian Bogor, Bogor. P. 187-327.

[6] Jin H. J., R. Tu, F. Xu, and S. F. Chen. 2011. Identification of Nitrogen Fixing Paenibacillus from Different Plant Rhizospheres and a Novel nifH Gene Detected in the P. stellifer1, Microbiology, 80 (1): 117-124.

[7] Chung YR, C. H. Kim, I. Hwang, and J. Chun. 2000. Paenibacilluskoreensis sp. nov., a new species that produces an iturin-like antifungal compound. Int. J. Syst. Evol. Microbiol. 50: 1495-1500.

[8] Hoult, B., and A. F. Tuxford. 1991. Toxin production by Bacillus pumilus. J ClinPathol (44): 455-458. Downloaded from jcp.bmj.com on November 8, 2012.

[9] Aslim, B., N. Saglam, and Y. Beyatli. 2002. Determination of some properties of Bacillus isolated from soil. Turk. J. Biol. (26): $41-48$

[10] Awais, M., A. A. Shah, A. Hameed, and F. Hasan. 2007. Isolation, Identification and Optimization of Bacitracin Produced by Bacillus sp. Pak. J. Bot., 39 (4): 1303-1312.

[11] Akhtar, M. S., U. Shakeel, Z. A. Siddiqui. 2010. Biocontrol of Fusariumwilt by Bacillus pumilus, Pseudomonas alcaligenes, and Rhizobium sp. on lentil. Department of Botany, Aligarh Muslim University, Aligarh - INDIA. Turk J Biol (34): 1-7.

[12] De-Bashan, L. E., J. P. Hernandez, Y. Bashan, and R. M. Maier. 2010. Bacillus pumilus ES4: Candidate plant growth-promoting bacterium to enhance establishment of plant in mine tailings. Environmental and Experimental Botani (69): 343-352.

[13] Afzal, A. and B. Asghari, 2008. Rhizobium and phosphate solubilizing bacteria improve the yield and phosphorus uptake in wheat (Triticumaestivum L). Int. J. Agric. Biol., 10: 85-8.

[14] Ahmed, Z.I., M. Ansar, M. Tariq and M.S. Anjum, 2008. Effect of different Rhizobium inoculation methods on performance of lentil in pothowar region. Int. J. Agric. Biol., 10: 85-8. 
[15] Kennedy, A.C. 1998. The rhizosphere and spermosphere. Pp 389407 In SILVIA et al. (Eds.) Principles and Application of Soil Microbiology. Prentice Hall. New Jersey.

[16] Jasinski, S.M. 2000. Peat. US Geologycal Survey: US Departement of the interior.

[17] Syekhfani. 2010. Hubungan hara tanah, air dan tanaman. Dasardasar pengelolaan tanah subur berkelanjutan. Putra Media Nusantara. 205 hlm.
[18] Simanungkalit, R.D.M., R.J. Roughley, and A. Indrasumunar. 1999. The effect of carrier material and moisture potential on the quality of legume inoculants. Penelitian Pertanian Tanaman Pangan 18(1): 64-70.

[19] Prihastutidan A. Harsono. 2012. Kemunduran kualitas pupukhayati Rhizobium. J. Sains dan Matematika 1 (1): 1-5. 